\title{
ANALYSIS OF FOODSERVICE SYSTEM AND NUTRITION EDUCATION OF RQ DAARUT TARBIYAH DEPOK, WEST JAVA
}

\author{
Khoirul Anwar, Nindy Sabrina, and Ikeu Ekayanti \\ Universitas Sahid, Indonesia \\ Bogor Agricultural University, Indonesia. \\ khoirul_anwar@usahid.ac.id
}

\begin{abstract}
Foodservice system is an important issue in educational institutions, including Islamic boarding schools. Nutrition intake for children and adolescents needs to be considered especially those who study with dormitory facilities and do not live with parents because usually spend a lot of time for various dense activities at school and in the dormitory. This study aims to analyse the implementation of foodservice system and improving nutrition knowledge of students and food handler of $R Q$ Daarut Tarbiyah Depok, West Java. This activity was held on December 2018 - January 2019 into RQ Daarut Tarbiyah Depok, West Java. The subjects of this activity were food handler and students. Nutrition education was given to students and food handler to improve nutrition knowledge, especially about the benefits of adequate nutrition in accordance with the needs at the age of adolescents and children, and the importance of maintaining a healthy body through the consumption of adequate amounts and types of food. Besides that, the foodservice system mostly was not in compliance in several standards such as menu planning, storing, and personal hygiene and sanitation. In conclusion, improving nutrition knowledge for students and food handlers in Islamic boarding schools and also good implementation of foodservice system is important to ensure a good nutritional status for students.
\end{abstract}

Keywords: Food Handler, Foodservice System, Islamic Boarding School, Students

\section{INTRODUCTION}

The foodservice system management is an integrated system activity, related to one another. Organizing food institutions and industries is an integrated program consisting of planning, procurement, storage, processing of food ingredients and serving or serving food on a large scale (Ministry of Health 2013). One of the communitybased educational institutions which is a popular place for education providers in Indonesia is the Islamic boarding school (Ministry of Health 2013). Like other school institutions, Islamic boarding schools also study many branches of science, but Islamic science is more deepened in Islamic boarding schools. One of the concerns in Islamic boarding schools is students who are superior human resources, including meeting their nutritional needs.

During the learning period in the Islamic boarding school, students are required to stay in the dormitory, and are required to be independent (Purwaningtiyas 2013). Food consumption for students is provided through the foodservice system management that is implemented by the Islamic boarding school. The implementation of the foodservice system in Islamic boarding schools is carried out by considering various factors including the services provided, facilities, institutional goal costs, human resources, and many other things (Palacio and Theis 2009).

Consumption of good food with regular meals will affect the level of nutritional adequacy of children and adolescents. Nutrition intake for children and adolescents needs to be considered especially those who study with dormitory facilities and do not live with parents because students who live in the dormitory usually spend a lot of time for various dense activities at school and in the dormitory (Zakiyah $N$ et al. 2011). Dense activities will make students rely solely on the time and portion of food provided by the organizing food in the dormitory. Luo et al. (2009) revealed that nutrient intake in students who lived in the dormitory was lower compared to students who did not live in the dormitory. Starting from this, it is important to to analyse the implementation of food service system and improving nutrition knowledge of students and food handler of RQ Daarut Tarbiyah Depok, West Java. 


\section{METHODS}

\section{Time and Location}

This activity was held on December 2018 - January 2019. This activity was carried out in RQ Daarut Tarbiyah Depok, West Java as an Islamic boarding school which is the center of the Quran recitation house in Depok area.

\section{Sampling}

Subjects in this activity were students and food handler of RQ Daarut Tarbiyah who were required to live in a dormitory. The selection of subjects is based on a number of established criteria such as: students who live in the dormitory, healthy, and are willing to take part in this activity until completion. The number of research subjects in the study was 75 people.

\section{Data collection and analysis}

There are two activities include nutrition education for Islamic boarding school students and food handler and observation of foodservice system management held by RQ Daarut Tarbiyah. The data of foodservice system management obtained through direct observation, and interviews with questionnaires. The data obtained about the foodservice system management was then analyzed descriptively to find out the quality of the running system. Quality assessment was done by comparing the current system with the standards of good foodservice system in Islamic boarding school.

\section{Nutrition education}

This activity was carried out in female Islamic boarding schools which involve Islamic boarding school students, food handler, and also teachers. There are several types of activities in this nutrition education, namely: 1) providing information on nutrition education, 2) question and answer session, and 3) measuring the nutritional status of students through weight and height measurements.

The material delivered to students and food handler in this activity included: 1) balanced nutrition, 2) the importance of fulfilling good nutrition for children and adolescents, and 3) foodservice systems carried out at institutions and how to evaluate it. The material was given through presentations using power points (PPT), followed by questions and answers. Furthermore, weight measurements were taken using a digital scale and height measurements using a stature meter.

\section{RESULTS AND DISCUSSION}

\section{Observation of foodservice system}

The implementation of foodservice system in RQ Daarut Tarbiyah Depok is managed by the family of the owner of the Islamic boarding school by providing kitchen facilities for cooking and room for the food handler. Foodservice system is carried out by Islamic boarding school to meet the nutritional needs of students to be able to move well. Food handler provide food for 3 meals at morning, afternoon and evening with a total of 120 servings for female students and 25 servings for male students at one meal. So that the food provided in a day for 3 meals is around 435 servings / day. Provision of food is done in special kitchens located in women's boarding schools, while male students must take food from female boarding schools to be taken to male boarding schools.

Based on observations made on the kitchen provided by the boarding school, the results obtained are divided into 6 variables, namely 1) Human Resources, 2) Equipment, 3) Selection of Foodstuffs, 4) Reception and storage of foodstuffs, 5) Processing of Foodstuffs, and 6) Distribution. The food organizer at RQ Daarut Tarbiyah consists of only 1 person who is responsible for all kitchen activities from the purchase, storage, processing, and provision of food. Food handler selected by owner of the Islamic boarding school only considers worker or food handler can cook and agree on a salary that will be given per month. Recruitment of workers has no other special requirements. Food handler at the Islamic boarding school on foodservice system do not yet have a sanitation hygiene course certificate. Based on ISN (Indicator Staffing Need) calculations, the number of food handler is not compliance because the number of workers needed is 7 people. Even though there are only 1 people, the implementation of food can be carried out well. During the food processing, food handlers always kiss their hands first, even though they do not use protective equipment when processing food.

The equipment available in the kitchen is divided into three namely storage, preparation, processing and serving tools. Available storage devices are refrigerators, dish racks, and tables. Preparation and processing tools available are knives, cutting boards, basins, pans, pans, and stoves. The serving tools available are trays and large plates. The equipment used for the implementation of foodservice system is well cared for so as to minimize food contamination. 

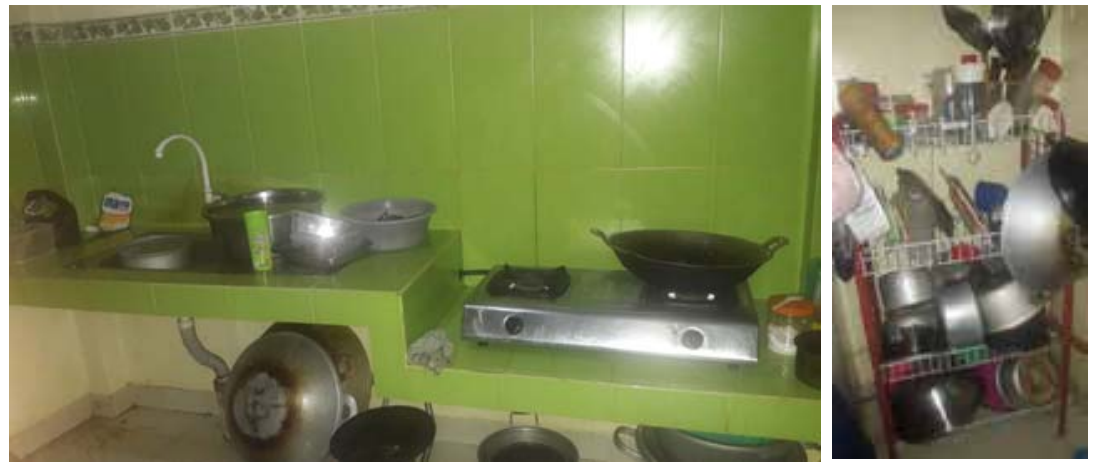

Figure 1. The equipment of foodservice system

The purchasing system carried out by the boarding school food organizers is done through an open market of buying, which means the purchase of materials is done directly by the organizer in the market (Palacio and Theis 2009). Food purchases are made by the food organizer every 3 days, and the amount and type of food to be purchased is adjusted to the inventory in the kitchen. Foodstuffs are purchased, then quality checks are carried out first in order to get good quality ingredients. The selection process is in accordance with the Republic of Indonesia Minister of Health Regulation No. 1096 / MENKES / PER / VI / 2011, namely 1). Raw (fresh) food must be in good condition, fresh and not damaged or change in shape, color and taste. 2). The type of flour and seeds must be in good condition, unchanging, not stained and moldy. 3). Packaged factory processed food must have a label and brand, be registered and have a registration number, the packaging is not damaged, has not expired, and the packaging is only for one use. 4). Unpackaged food must be fresh and fresh, not stale and does not contain harmful ingredients.

The food served in this system is centralized, that is, the distribution of food is carried out centrally in the kitchen of the Islamic boarding school. There are two methods of food distribution, namely centralization and decentralization (Palacio and Theis 2009). Food that has been processed and then served. Islamic boarding school students asked to the kitchen to take food that has been served buffet. Intake is done without using a particular correction. Islamic boarding school students are welcome to take their own food by bringing their own cutlery. Islamic boarding school students who had taken food then returned to the room to eat with friends.

There is a mismatch between the standards and the implementation of food carried out namely hygiene and sanitation. Food handler has not received training and hygiene and sanitation certificates. The kitchen used is still simple, so there are many non-conformities with the existing standards. The kitchen used is the same as the household kitchen, so there is no division of preparation, processing and serving rooms. The cooking place is still united with the warehouse. The door in the kitchen has not implemented a door that can close itself. Washing facilities for cooking utensils, foodstuffs and a place for washing hands are still united in one washing area.

\section{Nutrition education}

Nutrition education was carried out in female Islamic boarding schools which involve Islamic boarding school students, food handler, and also teachers. There are several types of activities in this nutrition education, namely: 1) providing information on nutrition education, 2) question and answer session, and 3) measuring the nutritional status of students through weight and height measurements. Nutrition education materials provided include, among others, balanced nutrition, the importance of fulfilling nutrition for children and adolescents, and the importance of organizing good food. The material was given by lecturers from the nutrition study program, Sahid University of Jakarta which was technically assisted by students of the nutrition study program, Sahid University of Jakarta.
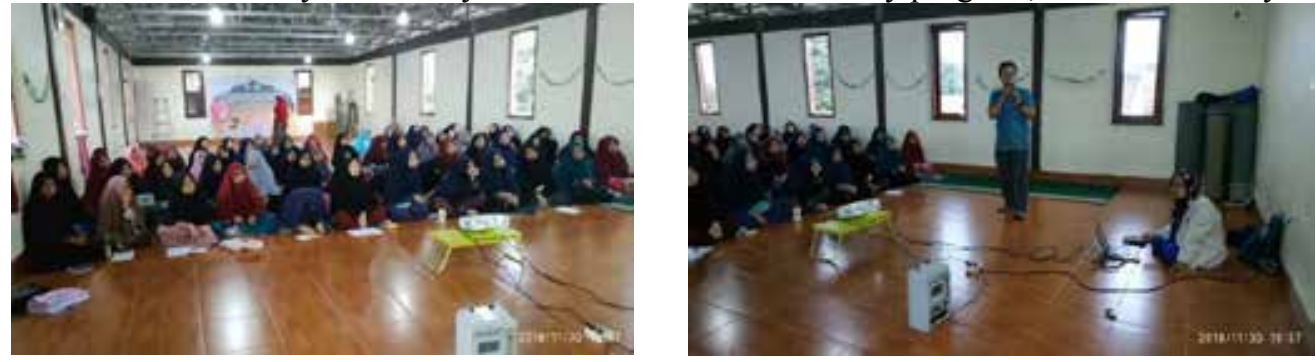

Figure 1. Nutrition education on Islamic Boarding School students, teachers and food handler After that, the activity continued with the measurement of the nutritional status of students through measurements of body weight and height. This is important to do in order to know the nutritional status conditions of students. 
Weight measurements are carried out using a digital scale and carried out alternately. In addition, height measurements are also carried out alternately using a stature meter. Weight and height measurements were carried out systematically by a team from the nutrition study program, Sahid university of Jakarta. The data obtained is then recorded and the nutritional status is calculated based on BMI-for-Age, Height-for-Age and Weight-for-Age to determine the category of nutritional status.
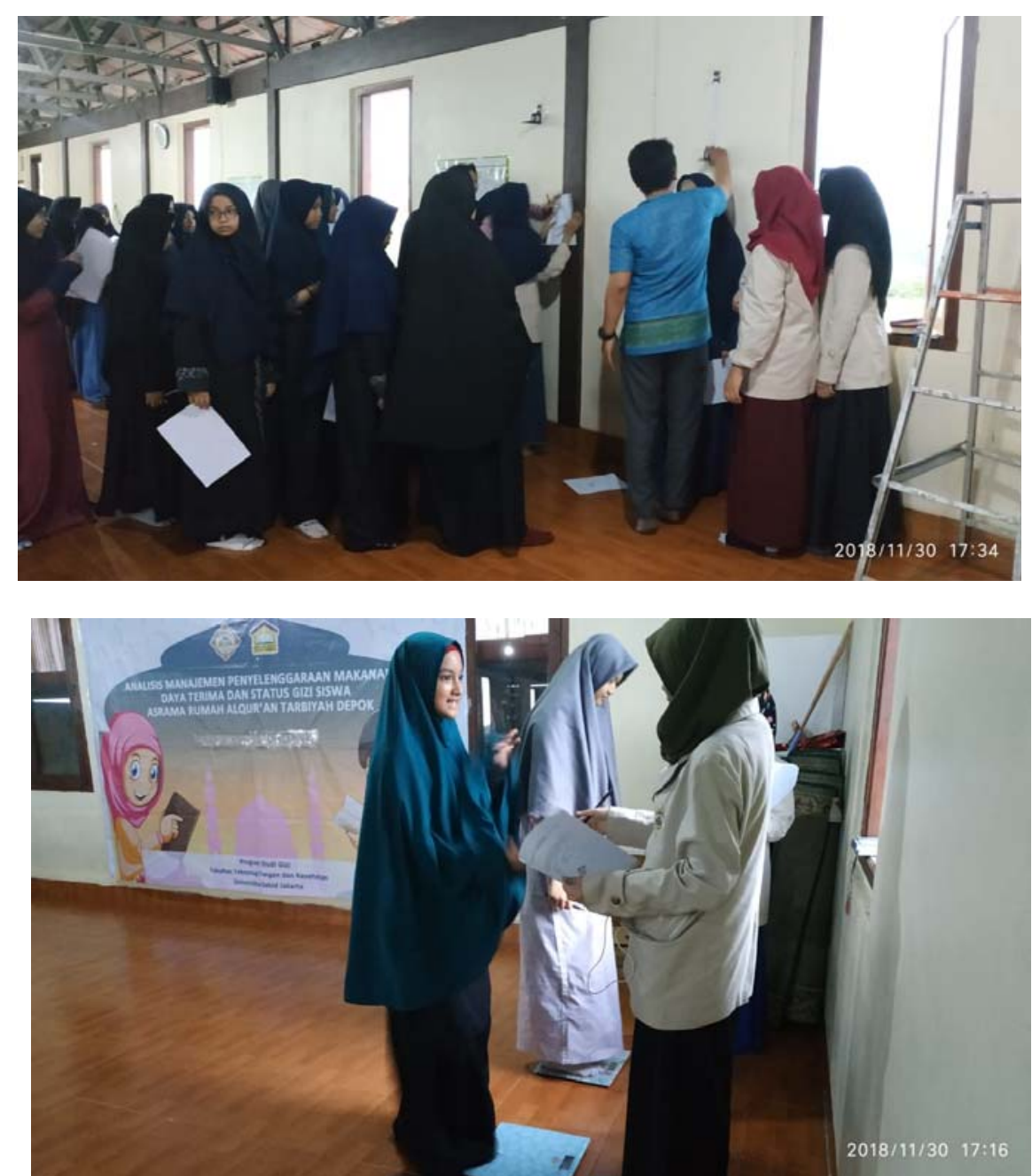

Figure 4. Measurement of weight of Islamic boarding school students

The benefits obtained from this activity include 1) Islamic boarding school students become more aware of balanced nutrition and the importance of maintaining adequate nutritional fulfilment, 2) knowledge of the nutritional status of students so that it can be used as an evaluation material to improve the nutritional status of students, 3) increased knowledge about food service standards, and 4) knowledge of the evaluation of the provision of food in boarding schools so that it can be done to improve the quality of the organization of food in boarding schools.

\section{CONCLUSION}

In conclusion, improving nutrition knowledge for students and food handlers in Islamic boarding schools and also good implementation of foodservice system is important to ensure a good nutritional status for students. 


\section{REFERENCES}

Luo, R., Shi, Y., Zhang, L., Liu, C., Rozelle, S., and Sharbono, B.. (2009). Malnutrition in China's rural boarding schools: the case of primary schools in Shaanxi Province. APJE, 29(4), 481-501.

Ministry of Health. (2011). Peraturan Menteri Kesehatan Republik Indonesia Nomor 1096/MENKES/PER/VI/2011 tentang Higiene Sanitasi Jasaboga. Jakarta (ID): Kemenkes RI.

Ministry of Health. (2013). Pedoman Penyelenggaraan dan Pembinaan Pos Kesehatan Pesantren. Jakarta (ID) : Kemenkes RI.

Ministry of Health. (2011). Peraturan Menteri Kesehatan Republik Indonesia Nomor 1096/MENKES/PER/VI/2011 tentang Higiene Sanitasi Jasaboga. Jakarta (ID): Kemenkes RI.

Palacio, J.P., Theis M. (2009). Introduction to Foodservice (11th ed). Ohio: Pearso Education

Sulistiyo, P. (2013). Gambaran Penyelenggaraan Makanan di Pondok Pesantren Al-Qodiri Kabupaten Jember [Skripsi]. Jember (ID): Fakultas Kesehatan Masyarakat, Universitas Jember

Zakiyah, N., Hidayati, F.N.R., dan Setyawan, I. (2011). Hubungan Antara Penyesuaian Diri dengan Prokrastinasi Akademik Siswa Sekolah Berasrama SMP N 3 Peterongan Jombang. Semarang (ID): Fakultas Psikologi Universitas Dipenogoro 